\title{
Simpanan Karbon Organik Dalam Sedimen Mangrove Terhadap Pasang Surut Di Pulau Bintan
}

\author{
Faradian Nurul Hapsari' ${ }^{1}$, Lilik Maslukah ${ }^{1 *}$, I Wayan Eka Dharmawan ${ }^{2}$, Sri Yulina Wulandari ${ }^{1}$ \\ ${ }^{1}$ Departemen Oseanografi, Fakultas Perikanan dan Ilmu Kelautan, Universitas Diponegoro \\ Jl. Prof. H. Sudarto, SH, Tembalang Semarang 50275 Indonesia \\ ${ }^{2}$ Pusat Penelitian Oseanografi, Lembaga Ilmu Pengetahuan Indonesia \\ Jl. Pasir Putih I, No. 1. Ancol Timur, Jakarta Utara Indonesia \\ E-mail : lilik_masluka@yahoo.com
}

\begin{abstract}
Abstrak
Ekosistem mangrove memberikan kontribusi terbesar pada kawasan pesisir dalam penyerapan karbon dari atmosfer serta penyimpanan karbon dalam bentuk biomassa ataupun terpendam di dalam sedimen. Variasi simpanan karbon pada sedimen mangrove sangat tergantung dengan struktur komunitas dan karakter oseanografi yaitu pasang surut. Tujuan penelitian ini adalah untuk menganalisis variasi nilai simpanan karbon sedimen mangrove di Pulau Bintan serta menganalisis hubungannya dengan karakter pasang surut. Lokasi penelitian memiliki karakter struktur komunitas mangrove yang berbeda, yaitu Desa Lagoi yang didominasi oleh jenis Ceriops tagal, dan Desa Kawal yang didominasi oleh jenis Rhizophora apiculata. Setiap lokasi penelitian dibagi menjadi tiga zona tegak lurus garis pantai berdasarkan parameter dominansi jenis. Parameter yang diukur yaitu ukuran butir sedimen, struktur komunitas mangrove, karbon sedimen dan pasang surut. Data karbon organik dan ukuran butir sedimen menggunakan metode wet sieving dan LOI, sedangkan untuk pasang surut diperoleh dari Badan Informasi Geospasial (BIG). Hasil penelitian menujukan bahwa simpanan karbon organik sedimen yang lebih besar ditemukan di wilayah yang memiliki ukuran butir yang lebih halus dengan arus dan tenggang waktu menuju surut yang lebih rendah serta rerata ukuran dan tinggi mangrove yang lebih besar. Tenggang waktu menuju surut lebih cepat akan mengakibatkan perputaran sedimen dan serasah cepat sehingga pengendapan sedimen dan serasah berkurang. Simpanan karbon organik sedimen mangrove memiliki perbedaan yang cukup signifikan di Kawal dan Lagoi dengan rerata sebesar 13,90 ton $\mathrm{C} \mathrm{ha}^{-1}$ dan 7,64 ton $\mathrm{C} \mathrm{ha}^{-1}$.
\end{abstract}

Kata Kunci : Mangrove, Karbon, Sedimen, Pasang Surut

\section{Abstract}

\section{Carbon Stock in Mangrove Sediments and Its Relationship to Tides on Bintan Island}

Mangrove ecosystems provide the largest contribution to coastal areas in absorbing carbon from the atmosphere and storing carbon in the form of biomass or buried in sediments. The variation of carbon storage in mangrove sediments is highly dependent on the community structure and the oceanographic character of the tides. The purpose of this study was to analyze variations in the value of carbon storage of mangrove sediments in Bintan Island and to analyze their relationship with tides. The research location has a different character of mangrove community structure, namely Lagoi Village which is dominated by the Ceriops tagal species, and Kawal Village which is dominated by the Rhizophora apiculata species. Each research location is divided into three zones perpendicular to the coastline based on the parameter of species dominance. Parameters measured were sediment grain size, mangrove community structure, sediment carbon and tides. Organic carbon and sediment grain size data using wet sieving and LOI methods, while tides were obtained from the Geospatial Information Agency (BIG). The results showed that larger organic sediment carbon stores were found in areas that had finer grain sizes with lower currents and time periods to tide and larger mean size and height of mangroves. The time to recede faster will result in rapid 
circulation of sediment and litter so that sediment and litter deposition is reduced. The organic carbon storage of mangrove sediments has a significant difference in Kawal and Lagoi with an average of 13.90 tonnes $C h a^{-1}$ and 7.64 tonnes $C h a^{-1}$.

Keywords : Mangroves, Carbon, Sediment, Tides

\section{PENDAHULUAN}

Kawasan pesisir adalah pertemuan antara wilayah laut dan daratan yang saling mempengaruhi satu sama lain (Dahuri et al., 2003). Wilayah pesisir mempunyai karakteristik khusus sebagai akibat interaksi antara prosesproses yang terjadi pada wilayah daratan dan lautan. Karakteristik kawasan pesisir yang meliputi zona intertidal dan supratidal, sangat dipengaruhi oleh faktor oseanografi seperti pasang surut. Karakter pasang surut dalam hal ini akan menentukan distribusi ukuran butir sedimen. Tiga ekosistem utama pada kawasan pesisir adalah terumbu karang, padang lamun dan mangrove yang merupakan ekosistem karbon biru.

Ekosistem mangrove memberikan kontribusi terbesar pada kawasan pesisir dalam penyerapan karbon dari atmosfer serta penyimpangan karbon dalam bentuk biomassa ataupun terpendam di dalam sedimen. Ekosistem mangrove sangat produktif dan berkontribusi sebagai sumber karbon organik (Analuddin et al., 2016). Potensi mangrove dalam menyimpan karbon lebih besar lima kali lipat dibandingkan hutan hujan tropis (Alongi, 2012). Murdiyarso et al. (2015) menjelaskan bahwa simpanan karbon tertinggi pada ekosistem mangrove ditemukan pada bagian sedimen. Sedimen dengan ukuran butir yang berbeda dapat mempengaruhi simpangan karbon yang ada pada sedimen tersebut. Sistem perakaran mangrove yang sangat rapat menyebabkan serasah dan bagian tubuh mangrove yang mati terperangkap di dalam wilayah sistem dan hanya sebagian kecil yang terekspor oleh pasang surut. Ekosistem mangrove merupakan ekosistem yang hidup di sepanjang pantai dan hidupnya dipengaruhi oleh pasang surut air laut (Nontji, 2007).

Periode pasang surut dapat digambarkan dari waktu puncak air pasang tinggi ke puncak air pasang tinggi berikutnya, atau waktu antara kondisi air surut ke kondisi air surut berikutnya. Periode pasang surut bisa bervariasi dari satu tempat dengan tempat lainnya. Perbedaan periode pasang surut ini biasa dikenal dengan nama tipe pasang surut. Tunggang pasang surut merupakan perbedaan antara ketinggian pasang naik dan pasang surut. Tunggang pasang surut menimbulkan suatu jarak per satuan waktu atau tenggang waktu dari surut menuju pasang atau sebaliknya.Tenggang waktu ini berpengaruh terhadap pengangkutan sedimen dan serasah yang merupakan sumber karbon dalam ekosistem mangrove.

Pulau Bintan merupakan pulau terbesar di Provinsi Kepulauan Riau yang terdiri atas ratusan pulau besar dan kecil. Hutan mangrove di Pulau Bintan memiliki potensi dalam menyimpan karbon cukup besar. Luasan hutan mangrove yang ada di Pulau Bintan sebesar \pm 9.164 ha (Irawan, 2013). Daerah yang memiliki potensi mangrove yang cukup besar yaitu daerah Kawal dan Lagoi. Desa Kawal merupakan salah satu desa yang terdapat di Kabupaten Bintan, Provinsi Kepulauan Riau. Desa Kawal memiliki ekosistem mangrove. Penelitian tentang potensi cadangan karbon sedimen pada ekosistem mangrove telah banyak dilakukan antara lain Hakim et al. (2016) di Dukuh Tapak, Semarang, Suryono et al. (2018) di Perancak, Bali, Lestariningsih et al. (2018) di Desa Timbulsloko, Demak, Jawa Tengah, Hickmah et al. (2021) di Karimunjawa dan beberapa lokasi lainnya. Penelitian yang telah dilakukan tersebut, belum pernah menganalisis bagaimana perbedaan simpanan karbon pada suatu wilayah yang memiliki karakteristik yang berbeda. Berdasarkan latar belakang tersebut, penelitian ini bertujuan untuk menganalisis variasi nilai simpanan karbon sedimen mangrove di Pulau Bintan dan menganalisis hubungannya dengan karakter oseanografi, khususnya pasang surut.

\section{MATERI DAN METODE}

Lokasi penelitian terletak di kawasan pesisir Desa Kawal dan Lagoi yang memiliki luasan hutan mangrove di Kawal sebesar $\pm 104,3$ ha dan Lagoi sebesar $\pm 60,5$ ha. Lokasi penelitian secara keseluruhan pada titik koordinat $0^{0} 0$ ' $17^{\prime \prime}$ 1034'52' LS dan 104012'47' -10802'27' BT. Penelitian ini dilakukan pada kawasan hutan mangrove di wilayah pesisir pulau Bintan yaitu daerah Kawal dan Lagoi. Hutan mangrove pada 
kedua kawasan memiliki jenis berbeda yang mana pada daerah Kawal Rhizophora apiculata lebih dominan dan memiliki diameter yang lebih besar, daerah Lagoi dominan Ceriops tagal. Pengambilan sampel data penelitian dilakukan pada 6 stasiun dimana 3 stasiun di setiap lokasi yang menandakan daerah dekat laut (seaward, $S$ ) yaitu stasiun 1 , diantara dekat laut dan darat (middle, $M$ ) untuk stasiun 2 dan stasiun 3 adalah daerah dekat darat atau pemukiman (landward, L) (Gambar 2) pada bulan Maret 2018.

Pengukuran Jarak dari pantai diukur dari pantai tegak lurus menuju stasiun (Gambar 2). Pada lokasi Kawal lebih jauh daripada lokasi Lagoi yaitu Kawal stasiun 1 sebesar 90 m, stasiun 2 sebesar $205 \mathrm{~m}$ dan stasiun 3 sebesar $354 \mathrm{~m}$. Pada lokasi Lagoi stasiun 1 sebesar 66,2 m, stasiun 2 sebesar $115,7 \mathrm{~m}$ dan stasiun 3 sebesar 204,48 m.

Data pendukung yang digunakan dalam penelitian ini antara lain data pasang surut BIG bulan Maret 2018 dan Desember 2017 dengan interval waktu $1 \mathrm{jam}$, data jenis mangrove, data ketebalan mangrove, data kerapatan mangrove serta data Peta Rupa Bumi Indonesia. Pengambilan data Struktur dan komposisi ekosistem dengan plot penelitian yang digunakan adalah $10 \mathrm{~m}$ x $10 \mathrm{~m}$ (Komiyama et al., 2005).

\section{Metode Pengambilan Sampel Sedimen}

Pengambilan sampel dilakukan dengan interval kedalaman $5 \mathrm{~cm}$ dari permukaan sedimen di masing-masing plot di tiga stasiun. Sedimen

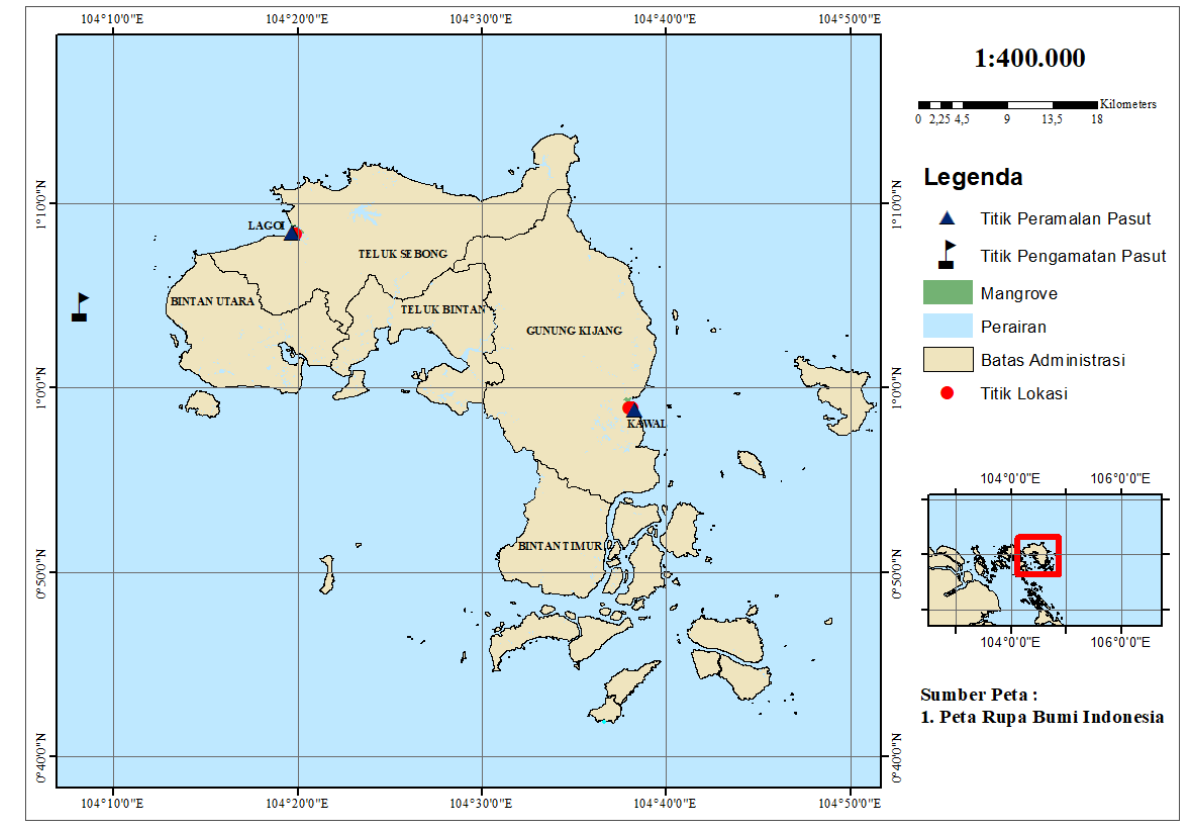

Gambar 1. Lokasi Penelitian

\begin{tabular}{|ccc|}
\hline Lokasi & Stasiun & $\begin{array}{c}\text { Jarak Stasiun dari } \\
\text { Pantai }(\mathbf{m})\end{array}$ \\
\hline Kawal & KS & 90 \\
& KM & 205 \\
& KL & 354 \\
Lagoi & LS & 66,2 \\
& LM & 115,7 \\
& LL & 204,48 \\
\hline
\end{tabular}

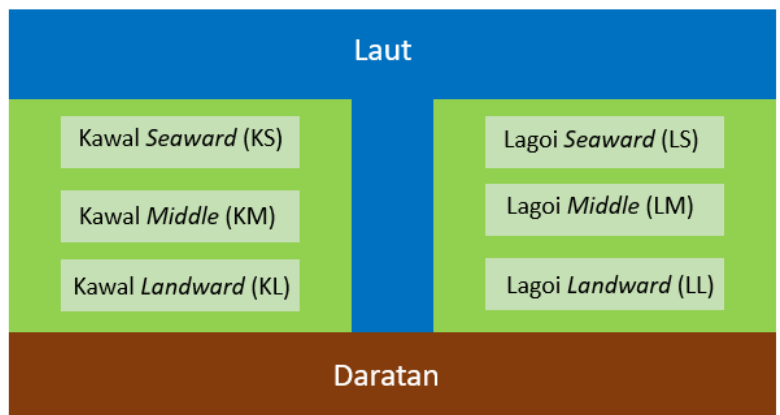

Gambar 2. Jarak dan Lokasi Pengambilan Sampel. 
dengan tekstur pasir, lanau, atau tanah liat dapat dilakukan pengambilan sampel dengan kedalaman $10 \mathrm{~cm}$. Pengambilan sampel sedimen mengunakan sediment corer berdiameter $5 \mathrm{~cm}$ dengan panjang $1 \mathrm{~m}$. Alat tersebut terbuat dari pipa PVC yang sudah dimodifikasi sehingga fungsi dan kegunaannya sama seperti sediment corer (Verisandria et al., 2018). Stasiun berjumlah 6 dengan mewakili 1 sampel per 1 stasiun. Sampel sedimen diambil dan dimasukkan kedalam plastik dengan diberi label per sampel, kemudian dianalisis di di Laboratorium Pusat Penelitian Oseanografi LIPI, Jakarta Utara.

\section{Analisis Jenis Ukuran Butir Sedimen}

Analisis butir sedimen dilakukan untuk mengetahui ukuran butir sedimen serta dapat mengetahui jenis sedimen yang ada di perairan tersebut. Analisis ukuran butir dilakukan menggunakan metode wet sieving seperti yang telah dilakukan oleh Lestariningsih et al. (2018). Sedimen dimasukkan dalam gelas ukur 1 liter dan ditambahkan aquades sampai volumenya 1 liter untuk dilakukan proses pemipetan dengan jarak dan waktu pemipetan. Selanjutnya dilakukan perhitungan nilai presentase setiap fraksinya. Klasifikasi ukuran butir dilakukan berdasarkan klasifikasi Wentworth (1992). Penentuan jenis sedimen dilakukan berdasarkan klasifikasi Diagram Segitiga Shepard tahun 1954 (Gemilang et al., 2018)

\section{Analisis Karbon Organik Total}

Analisis karbon organik total menggunakan metode pengabuan kering (loss on ignition). Sampel sedimen sebanyak $10 \mathrm{gr}$ diletakan di cawan, kemudian dikeringkan dengan suhu $100^{\circ} \mathrm{C}$ untuk menghilangkan kadar air didalamnya. Kemudian didinginkan lalu ditimbang sebagai berat awal. Sampel yang telah dicatat berat awalnya kemudian dipanaskan hingga menjadi abu menggunakan muffle furnace dengan suhu $550{ }^{\circ} \mathrm{C}$ kurang lebih selama 8 jam. Penetapan kandungan organik karbon dilakukan dengan mengkonversi hasil pengukuran menggunakan LOI dengan faktor konversi sebesar 2,07 yang merupakan perkiraan rasio bahan organik terhadap konsentrasi organik karbon (Kauffman dan Donatto, 2012). Selanjutnya dilakukan perhitungan karbon tanah dengan persamaan yang dilakukan oleh Howard J. et al. (2014) menggunakan persamaan 1 :
$\mathrm{Ct}\left(\mathrm{g} \mathrm{C} \mathrm{cm}^{-2}\right)=\% \mathrm{C} \times \mathrm{BD} \times \mathrm{SDI}$.

Keterangan : $\mathrm{Ct}=$ Karbon Organik Sedimen $(\mathrm{g} \mathrm{C}$ $\left.\mathrm{cm}^{-2}\right) ; \% \mathrm{C}=$ Kandungan Karbon Organik; BD = Soil Bulk Density $\left(\mathrm{g} \mathrm{cm}^{-3}\right)$; SDI = Soil Depth Interval $(\mathrm{cm})$

Perhitungan kandungan karbon organik tanah per hektar menggunakan persamaan 2 :

$\mathrm{C}_{\text {tanah }}\left(\right.$ ton $\left.\mathrm{C} \mathrm{ha}^{-1}\right)=\mathrm{Ct}\left(\mathrm{g} \mathrm{C} \mathrm{cm}^{-2}\right) \times 100$

Keterangan $: \mathrm{C}_{\text {tanah }}=$ Karbon Organik Sedimen per hektar $\left(\right.$ ton $\left.\mathrm{C} \mathrm{ha}^{-1}\right) ; \mathrm{Ct}=$ Karbon Organik Sedimen $\left(\mathrm{g} \mathrm{C} \mathrm{cm}^{-2}\right) ; 100=$ Faktor Konversi dari $\left(\mathrm{g} \mathrm{C} \mathrm{cm}^{-2}\right) \mathrm{ke}\left(\right.$ ton $\left.\mathrm{C} \mathrm{ha}^{-1}\right)$

\section{Analisis Pasang Surut}

Metode Admiralty digunakan untuk menganalisis data pasang surut dalam rentang waktu pengamatan yang pendek (15 atau 29 hari pengamatan). Pencarian komponen pasang surut suatu perairan metode ini menerapkan 8 skema dengan 3 buah tabel bantuan. Data pasang surut dari Badan Informasi Geospasial (BIG) diperoleh website http://tides.big.go.id/ (Rampengan, 2013). Data pasang surut diolah dengan software microsoft excel 2016 menggunakan metode Admiralty. Komponen pasang surut yang akan dianalisis dengan metode Admiralty adalah S0, M2, S2, N2, K1, O1, M4, MS4, K2, P1 dan selanjutnya ditentukan $M L W L, M H W L, L L W L$, $H H W L$, pasang tertinggi $(H W L)$ dan surut terendah $(L W L)$. Penentuan tipe pasang surut akan ditentukan menggunakan bilangan Formzahl dengan persamaan 3 :

$$
F=\frac{\mathrm{K} 1+\mathrm{O} 1}{\mathrm{M} 2+\mathrm{S} 2}
$$

Keterangan : $\mathrm{F}=$ Bilangan Formzahl; $\mathrm{K} 1=$ Amplitudo komponen pasang surut tunggal utama yang disebabkan gaya tarik matahari; $\mathrm{O} 1=$ Amplitudo komponen pasang surut tunggal utama yang disebabkan gaya tarik bumi. M2 = Amplitudo komponen pasang surut tunggal ganda yang disebabkan gaya tarik bulan; $\mathrm{S} 2=$ Amplitudo komponen pasang surut tunggal ganda yang disebabkan gaya tarik matahari

Data pasang surut yang telah diolah kemudian diverifikasi dengan data IPASOET BIG. Verifikasi dilakukan menggunakan perhitungan RMSE (Root Mean Square Error) 
yang merupakan metode alternatif untuk mengevaluasi teknik peramalan yang digunakan untuk mengukur tingkat akurasi hasil prakiraan suatu peramalan. Menurut Ismunarti et al. (2020), RMSE menggambarkan seberapa tersebarnya selisih nilai peramalan dan pengamatan. RMSE dihitung menggunakan persamaan 4 :

$$
\text { RMSE }=\sqrt{\frac{\sum\left(X_{1 i}-X_{2 i}\right)^{2}}{n}}
$$

Keterangan : RMSE $=$ Selisih Nilai Peramalan Dan Pengukuran; $\quad X_{1 \mathrm{i}}=$ Nilai Peramalan; $\mathrm{X}_{2 \mathrm{i}}$ $=$ Nilai Pengamatan $; n=$ Jumlah Data

Perhitungan tenggang waktu pasang surut (Gambar 3) dihitung mulai saat kondisi air laut berada pada reratanya (MSL) sampai saat kondisi laut berada pada kondisi pasang tertinggi dan MSL menuju surut terendah. Hal tersebut dikarenakan mangrove tumbuh di daerah pasang surut, pada ketinggian di antara laut rata-rata level (MSL) dan pasang tinggi (McIvor et al, 2013).

\section{Analisis Data}

Data sedimen karbon, komposisi ukuran butir dan tenggang waktu pasang surut dianalisis secara deskriptif menggunakan grafik untuk memperoleh nilai rerata dan standar deviasi pada setiap lokasi. Uji $\mathrm{t}$ diterapkan untuk mengidentifikasi signifikansi dari perbedaan nilai rerata antar lokasi pada taraf siginifikansi $(\mathrm{p}<0,05)$.

\section{HASIL DAN PEMBAHASAN}

Setiap lokasi penelitian menghasilkan jumlah simpanan karbon pada sedimen yang berbeda dipengaruhi oleh banyaknya bahan organik yang ditemukan, struktur komunitas mangrove, ukuran sedimen dan pasang surut. Nilai kandungan karbon organik sedimen (Tabel 1).

Nilai simpanan karbon sedimen dan rerata simpanan karbon sedimen di Kawal memiliki nilai yang lebih tinggi daripada di Lagoi (Gambar 4). Rerata simpanan karbon sedimen di Kawal memiliki nilai 13,90 ton $\mathrm{C}$ ha ${ }^{-1}$. Sementara itu, di Lagoi memiliki nilai rerata kandungan karbon sedimen sebesar 7,64 ton $\mathrm{C} \mathrm{ha}{ }^{-1}$. Setelah dilakukan uji t nilai rerata simpanan kandungan karbon sedimen pada kedua lokasi memiliki perbedaan yang signifikan $(\mathrm{P}<0,05)$. Saidy $(2018)$ menjelaskan jumlah bahan organik pada permukaan tanah dtentukan oleh produktivitas serasah, yang dapat didefinisikan sebagai jumlah serasah yang jatuh pada permukaan tanah per satuan luas dalam periode tertentu. Selain itu, ukuran butir sedimen dapat mempengaruhi simpanan karbon sedimen mangrove. Tidak hanya itu saja pengaruh pergerakan pasang surut di kedua lokasi yang berbeda dapat memengaruhi pergerakan sedimen dan juga sistem perakaran mangrove sebagai penahan serasah. Rerata simpanan karbon sedimen di Kawal dan Lagoi memiliki nilai yang lebih lebih rendah dibandingkan dengan penelitian yang dilakukan oleh Ati et al. (2014) di Tanjung Lesung, Banten dengan simpanan karbon sedimen sebesar 27,92 ton $\mathrm{C}$ ha $^{-1}$. Sedangkan untuk presentase karbon organik sedimen $(\% \mathrm{C})$ untuk Kawal dan Lagoi yang memiliki rerata nilai karbon organik sedimen $10,35 \%$ dan $4,84 \%$ (Tabel 1), lebih tinggi dibandingkan dengan penelitian yang dilakukan Hakim et al. (2016) di Tapak, Kota Semarang nilai rerata $4,4 \%$.

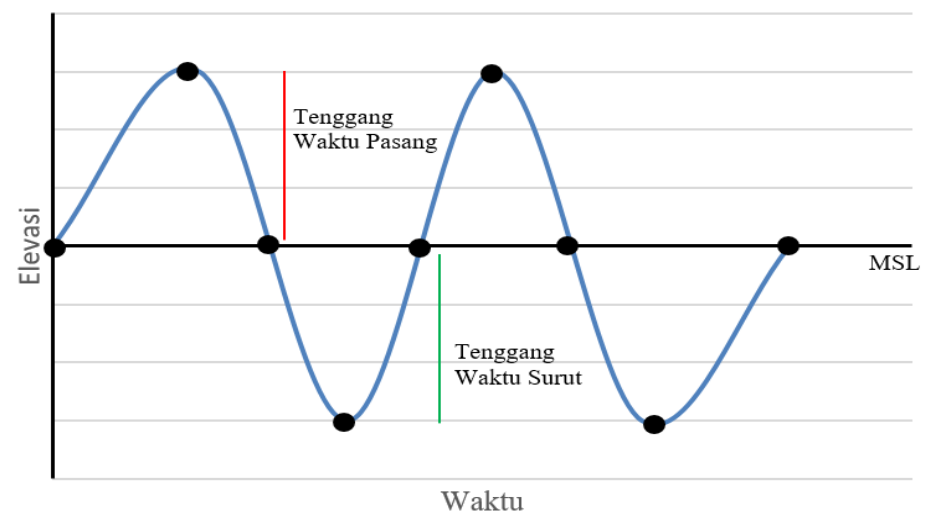

Gambar 3. Perhitungan Tenggang Waktu 
Tabel 1. Kandungan Karbon Organik Sedimen

\begin{tabular}{ccccc}
\hline Lokasi & Stasiun & $\mathrm{C}(\%)$ & $\mathrm{C}\left(\mathrm{g} \mathrm{cm}^{-2}\right)$ & $\mathrm{C}$ (ton ha $\left.{ }^{-1}\right)$ \\
\hline \multirow{4}{*}{ Kawal } & $\mathrm{KL}$ & 7,35 & 0,12 & 12,13 \\
& $\mathrm{KM}$ & 11,23 & 0,14 & 14,59 \\
& $\mathrm{KS}$ & 12,49 & 0,15 & 14,99 \\
& Rerata & 10,35 & 0,13 & 13,91 \\
& LL & 6,05 & 0,09 & 9,38 \\
Lagoi & LM & 4,37 & 0,07 & 6,99 \\
& LS & 4,1 & 0,06 & 6,56 \\
& Rerata & 4,84 & 0,07 & 7,64 \\
\hline
\end{tabular}

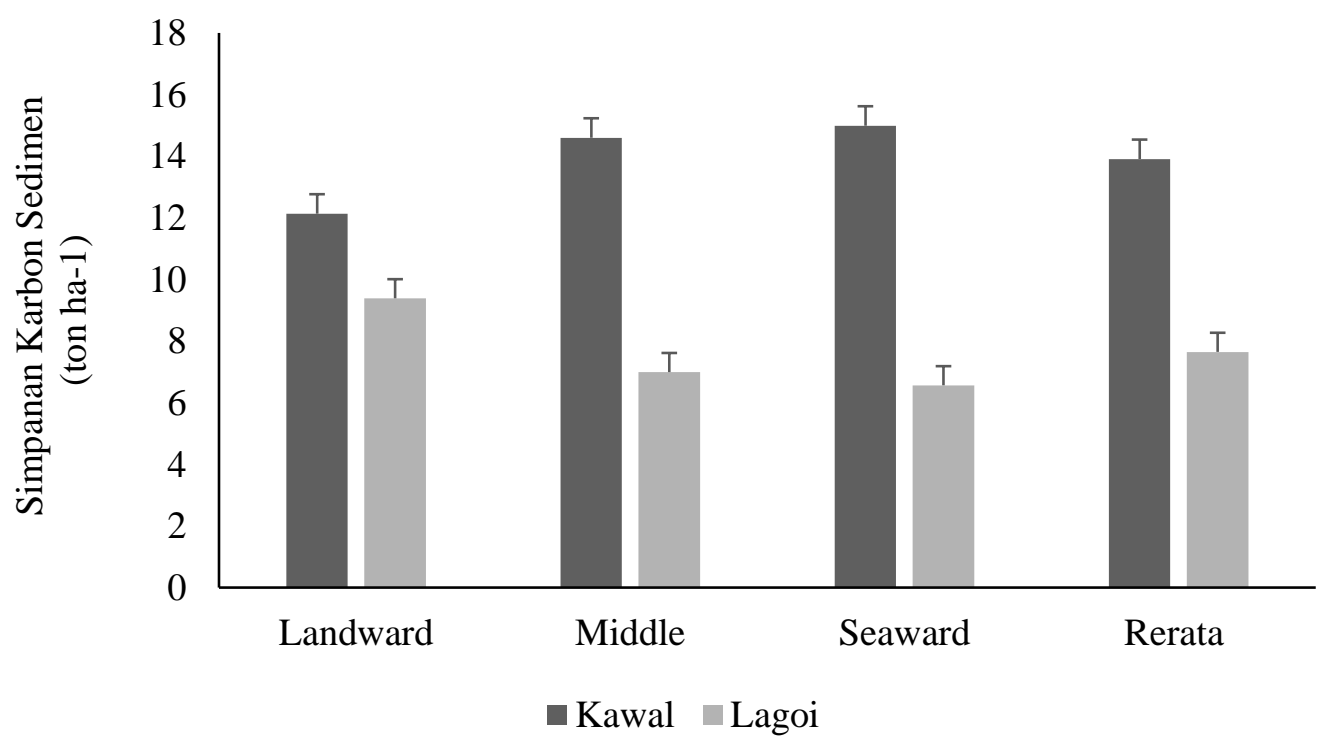

Gambar 4. Grafik Rerata Simpanan Karbon

\section{Analisis Ukuran Butir dan Jenis Sedimen}

Ukuran butir dan jenis sedimen pada setiap lokasi memiliki komposisi yang berbeda (Gambar 5). Persentase ukuran butir dan jenis sedimen di setiap stasiun kemudian dibuat rerata untuk mengetahui rerata di setiap lokasi penelitian. Persentase rerata sedimen Kawal lebih halus yaitu $54 \%$ sand (pasir), $18 \%$ silt, $19 \%$ clay, $5 \%$ pebbels dan $4 \%$ granules. Selanjutnya untuk Lagoi memiliki presentase rerata sedimen $63 \%$ sand (pasir), $11 \%$ silt, $13 \%$ clay, $4 \%$ pebbels dan $9 \%$ granules. Keterkaitan cadangan karbon pada sedimen diduga dipengaruhi oleh bahan organik, jenis sedimen dan letak stasiun penelitian. Hal ini didukung penelitian oleh Hakim et al (2016) sedimen dengan struktur lumpur memiliki kandungan karbon organik lebih banyak dibandingkan dengan sedimen pasir. Kondisi pasang air laut pada saat penelitian mempengaruhi sedimen yang terbawa arus. Saat kondisi pasang intrusi air laut akan membawa partikel sedimen ke daerah belakang mangrove dan ketika surut maka berbagai partikel tersebut akan tertarik kembali bersama dengan air laut yang tertarik ke laut, partikel pasir akan terlebih dahulu mengendap karena ukurannya jauh lebih besar.

\section{Pasang Surut}

Pasang surut air laut memiliki karakteristik, tipe dan elevasi yang berbeda pada setiap lokasi yang mana pasang surut tersebut memiliki pasang tertinggi, surut terendah, RMSE, nilai Formzahl dan tipe pasang surut (Tabel 2).

Nilai Formzahl dari kedua lokasi berbeda tetapi untuk tipe pasang surut sama yaitu campuran condong harian ganda (Gambar 6 dan Gambar 7). Hal tersebut dikarenakan nilai Formzahl di Kawal dan Lagoi berada pada nilai 
$0,26<\mathrm{F}<1,5$ (Tabel 2). Perbedaan nilai Formzahl dikarenakan komponen pasang surut (Tabel 3) yang berbeda diakibatkan dari nilai ketinggian pasang dan surut yang berbeda di Kawal dan Lagoi. Rampengan (2013) menjelaskan bahwa tunggang air pasang surut (tidal range) dapat memperhatikan puncak pasang dan surut terendah yang dapat dilihat dari garfik pasang surut (Gambar 6 dan Gambar 7) yang telah diverifikasi. Pasang tertinggi di Kawal sebesar $102 \mathrm{~cm}$ dan surut terendah sebesar $-165 \mathrm{~cm}$ (Tabel 2). Sedangkan di Lagoi memiliki nilai pasang tertinggi sebesar $92 \mathrm{~cm}$ dan surut terendah -135 $\mathrm{cm}$ (Tabel 2). Pasang surut yang berbeda pada setiap lokasi karena dipengaruhi oleh topografi dasar laut, lebar selat dan bentuk teluk. Hasil penelitian Hamunal et al. (2018) di Laut Mimika, Papua yang memiliki pasang tertinggi mencapai $431,53 \mathrm{~cm}$.

Hasil verifikasi data peramalan dan data pengamatan pasang surut di Kawal disajikan pada Gambar 6 dan Lagoi pada Gambar 7. Berdasarkan nilai RMSE yang tertera pada Tabel 2, dapat dijelaskan bahwa hasil peramalan baik dan valid, dengan nilai RMSE untuk Kawal dan Lagoi secara berurutan sebesar 0,49 dan 0,32.

Tenggang waktu menuju pasang dan surut di Lagoi dan Kawal berbeda. Rerata tenggang waktu menuju surut di Kawal lebih kecil daripada di Lagoi, namun rerata tenggang waktu menuju pasang nilainya hampir sama (Gambar 8). Pasang surut di lokasi Kawal dihitung memiliki rerata tenggang waktu menuju surut sebesar $17,37 \mathrm{~cm}$ $\mathrm{jam}^{-1}$ dan menuju pasang sebesar $22,75 \mathrm{~cm} \mathrm{jam}^{-1}$. Sementara itu, di Lagoi lebih tinggi rerata tenggang waktu menuju surut sebesar $19,12 \mathrm{~cm}$ $\mathrm{jam}^{-1}$ dan menuju pasang sebesar $22,5 \mathrm{~cm} \mathrm{jam}^{-1}$. Setelah dianalisis dengan uji t didapatkan hasil pada rerata tenggang waktu menuju surut perbedaanya cukup signifikan $(\mathrm{P}<0,05)$. Sedangkan hasil rerata tenggang waktu menuju pasang di kedua lokasi perbedaannya tidak cukup signifikan $(\mathrm{P}>0,05)$.

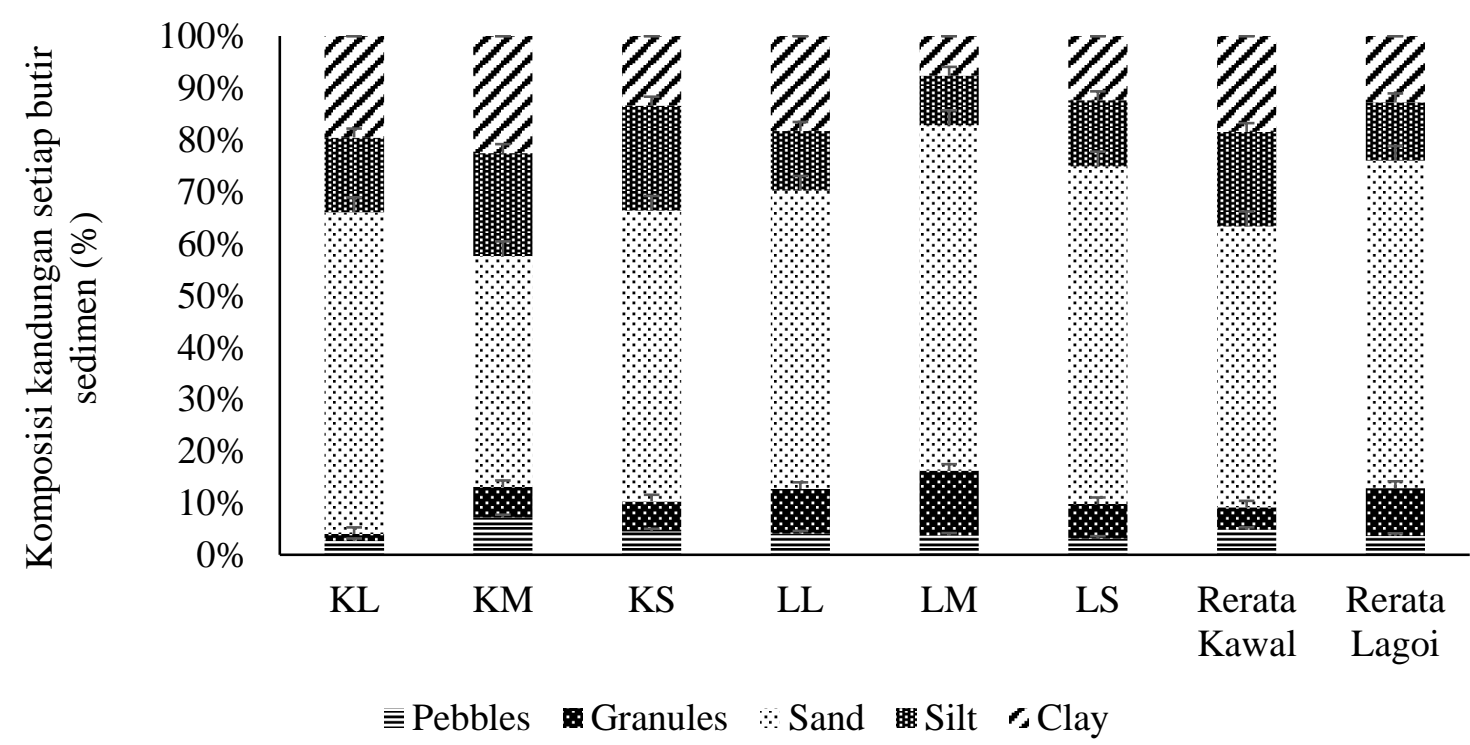

Gambar 5. Ukuran dan Jenis Butir Sedimen di Lokasi Penelitian (Keterangan: KS (Kawal seaward), KM (Kawal middle), KL (Kawal landward), LS (Lagoi seaward), LM (Lagoi middle), LL (Lagoi landward))

Tabel 2. Data Pasang Surut di Lokasi Penelitian

\begin{tabular}{cccccc}
\hline Lokasi & $\begin{array}{c}\text { Surut } \\
\text { Terendah }(\mathrm{cm})\end{array}$ & $\begin{array}{c}\text { Pasang } \\
\text { Tertinggi }(\mathrm{cm})\end{array}$ & RMSE & Formzahl $(\mathrm{F})$ & Tipe \\
\hline Kawal & -165 & 102 & 0,49 & 1,409 & $\begin{array}{c}\text { Pasang surut campuran, } \\
\text { condong harian ganda }\end{array}$ \\
\hline
\end{tabular}


Tabel 3. Komponen Pasang Surut di Lokasi Penelitian

\begin{tabular}{|c|c|c|}
\hline \multirow{2}{*}{ Komponen Pasang Surut } & \multicolumn{2}{|c|}{$\mathrm{A}(\mathrm{cm})$} \\
\hline & Kawal & Lagoi \\
\hline $\mathrm{S}_{0}$ & 0,0 & 0,0 \\
\hline $\mathrm{M}_{2}$ & 56,5 & 58,6 \\
\hline $\mathrm{S}_{2}$ & 14,3 & 16,3 \\
\hline $\mathrm{N}_{2}$ & 11,2 & 10,8 \\
\hline $\mathrm{K}_{1}$ & 48,8 & 33,7 \\
\hline $\mathrm{O}_{1}$ & 51.0 & 33,9 \\
\hline $\mathrm{M}_{4}$ & 0,2 & 0,3 \\
\hline $\mathrm{MS}_{4}$ & 0,4 & 0,4 \\
\hline $\mathrm{K}_{2}$ & 3,8 & 4,4 \\
\hline $\mathrm{P}_{1}$ & 16,1 & 11,1 \\
\hline
\end{tabular}

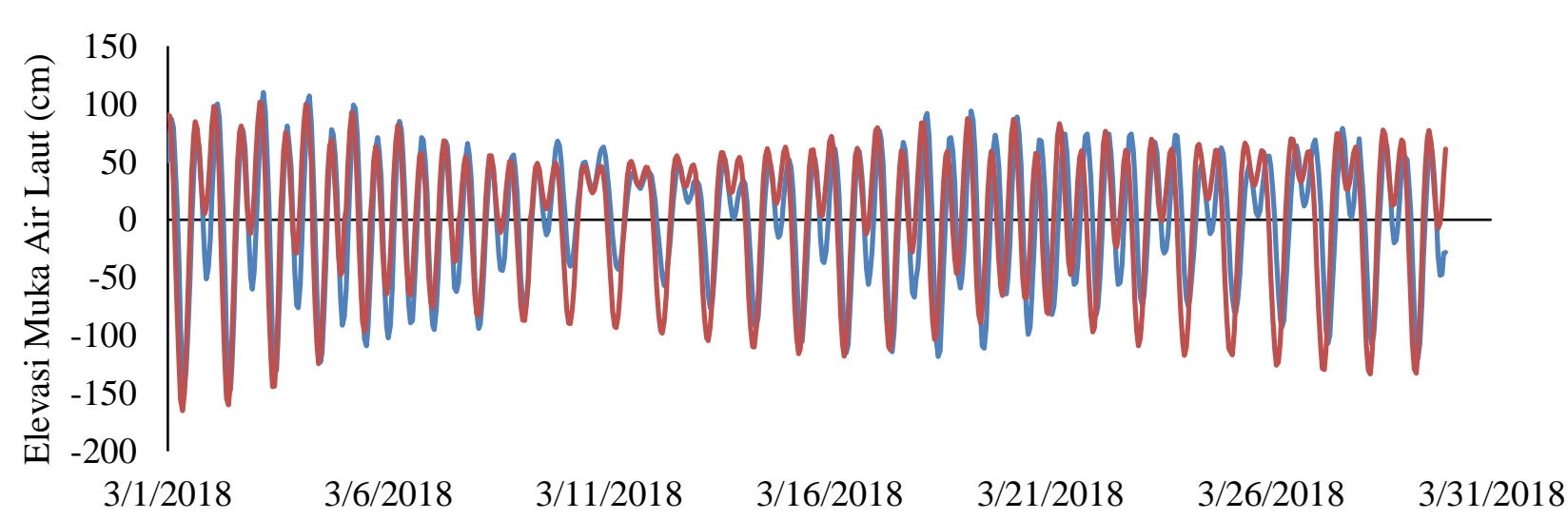

—Pengamatan —Peramalan

Gambar 6. Grafik Pasang Surut Kawal bulan Maret 2018

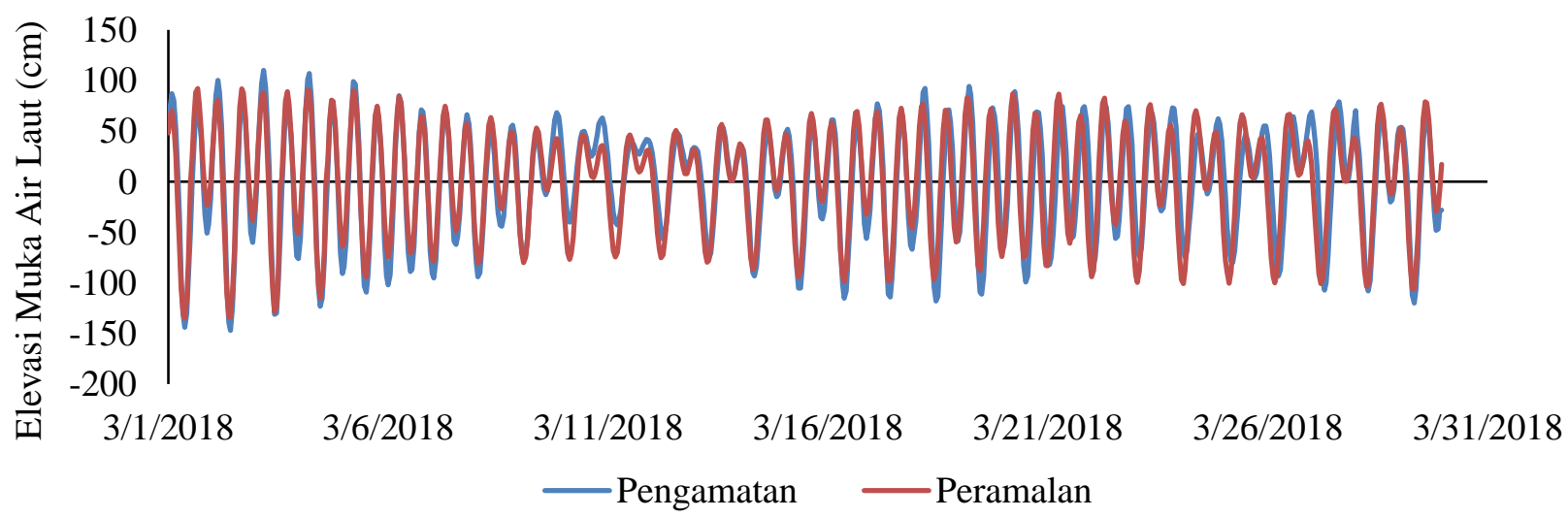

Gambar 7. Grafik Pasang Surut Lagoi bulan Maret 2018

Perbedaan tenggang waktu menuju pasang dan surut yang berbeda dipengaruhi oleh ketinggian pasang dan surut, topografi pantai, dan lebar selat atau teluk. Lokasi Lagoi yang berbatasan dengan laut lepas lebih cepat perubahan menuju pasang dan surut. Sedangkan di Kawal yang dibatasi oleh pulau Kamal perubahan pasang menuju surut maupun sebaliknya lebih lambat. Perubahan ketinggian menuju pasang dan surut inilah yang dapat 
mengakibatkan perputaran sedimen dan juga serasah mangrove yang ada di Kawal dan Lagoi berbeda. Lagoi yang memiliki tenggang waktu yang lebih tinggi mengakibatkan proses keluar masuknya sedimen dan serasah dari laut dan darat lebih cepat sehingga berkurangnya masukan karbon yang didapat dari serasah dan juga ukuran butir sedimen yang berbeda ketika pasang air laut masuk ke daerah mangrove membawa subtrat yang kemudian ketika surut maka subtrat yang banyak terendap adalah pasir.

Bulan Desember (mewakili musim Barat) memiliki rerata tenggang waktu menuju pasang dan surut yang lebih tinggi daripada bulan Maret di Kawal dan Lagoi (Gambar 9). Lokasi di Kawal rerata tenggang waktu menuju pasang pada musim peralihan sebesar $22,76 \mathrm{~cm} \mathrm{jam}^{-1}$ dan musim barat sebesar 22,87 $\mathrm{cm} \mathrm{jam}^{-1}$. Sementara itu, di Lagoi rerata tenggang waktu menuju pasang pada musim peralihan $22,51 \mathrm{~cm} \mathrm{jam}^{-1}$ dan musim barat sebesar $22,53 \mathrm{~cm} \mathrm{jam}^{-1}$. Selanjutnya untuk rerata tenggang waktu menuju surut di Kawal pada musim peralihan sebesar $17,37 \mathrm{~cm} \mathrm{jam}^{-1}$ dan musim barat sebesar $17,91 \mathrm{~cm} \mathrm{jam}^{-1}$. Sedangkan di Lagoi rerata tenggang waktu menuju surut pada musim peralihan sebesar $19,12 \mathrm{~cm} \mathrm{jam}^{-1}$ dan musim barat sebesar 19,31 $\mathrm{cm} \mathrm{jam}^{-1}$. Setelah dianalisis dengan uji t didapatkan hasil pada rerata tenggang waktu menuju pasang maupun surut pada musim barat perbedaanya tidak cukup signifikan $(\mathrm{P}>0,05)$.

\section{Mangrove}

Indeks nilai penting suatu jenis berkisar antara $0-300$, nilai penting ini memberikan gambaran tentang peranan suatu jenis mangrove dalam ekosistem dan dapat juga digunakan untuk menentukan dominasi suatu spesies dalam komunitas (Romadhon et al.,2008). Lokasi Kawal memiliki simpanan karbon yang tinggi didominasi oleh Lumnitzera litorea dan Rhizophora apiculata berdasarkan indeks nilai pentingnya (Tabel 4).

Hadi et al. (2015) berpendapat bahwa Rhizophora apiculata memiliki kemampuan adaptasi terhadap linkungan dengan bentuk akarnya berupa akar tunjang yang besar. Akar tunjang pada Rhizophora apiculata membentuk sistem antar tegakan yang dapat memperangkap sedimen sehingga kandungan sedimen menjadi bertambah. Tidak hanya itu saja Rhizophora apiculata memiliki morfologi daun dengan rerata ukuran luas permukaan lebih besar daripada Ceriops tagal, dimana ukuran tersebut dapat mempengaruhi kandungan serasahnya. Lokasi penelitian di Lagoi didominasi oleh Ceriops tagal
(Tabel 4 ). Jenis mangrove Ceriops tagal memiliki jenis yang sama seperti Rhizophora apiculata yaitu akar tunjang. Akar tunjang dari Ceriops tagal bentuknya kecil dan sangat rapat, sehingga untuk memperangkap sedimen kurang optimal. Perbedaan jenis inilah yang menyebabkan simpanan karbon sedimen perbedaanya cukup signifikan di Kawal dan Lagoi. Kawal memiliki ketebalan pada stasiun 1 sebesar $130 \mathrm{~m}$, stasiun 2 sebesar $120 \mathrm{~m}$ dan stasiun 3 sebesar $100 \mathrm{~m}$ (Tabel 4). Pada lokasi Lagoi memiliki ketebalan mangrove yang lebih kecil yaitu staisun 1 sebesar $100 \mathrm{~m}$, stasiun 2 sebesar $90 \mathrm{~m}$ dan stasiun 3 sebesar $80 \mathrm{~m}$. Mangrove yang lebar dapat mempengaruhi produksi serasahnya. Hal ini sesuai dengan penelitian Dharmawan et al. (2016).

Jumlah mangrove juga dapat mempengaruhi tutupan kanopi mangrove. Pendapat ini didukung oleh penelitian Mahmudi et al. (2011) dimana ketipisan kanopi dan morfologi daun juga ikut mempengarhui besar kecilnya serasah. Kawal memiliki tutupan mangrove lebih sedikit dan Lagoi lebih besar (Tabel 5) dibandingkan hasil penelitian oleh Coremap-CTI LIPI pada tahun 2018 di pulau Abang Besar, Batam sebesar $82,42 \%$ dimana pada daerah tersebut juga didominasi oleh Rhizophora apiculata seperti di Kawal (Tabel 4). Tutupan kanopi di Kawal lebih sedikit diakibatkan oleh

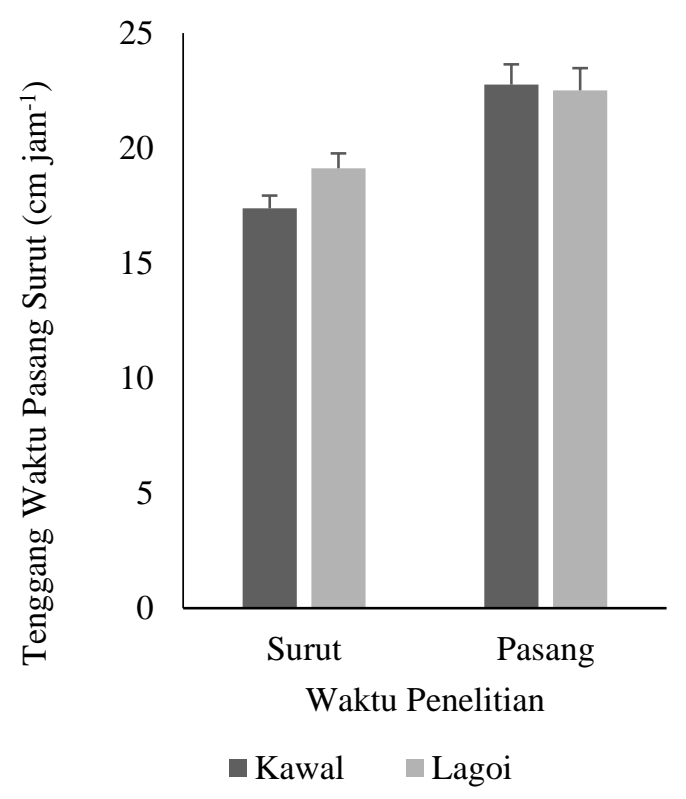

Gambar 8. Tenggang Waktu menuju Pasang dan Surut bulan Maret 2018 di Lokasi Penelitian 


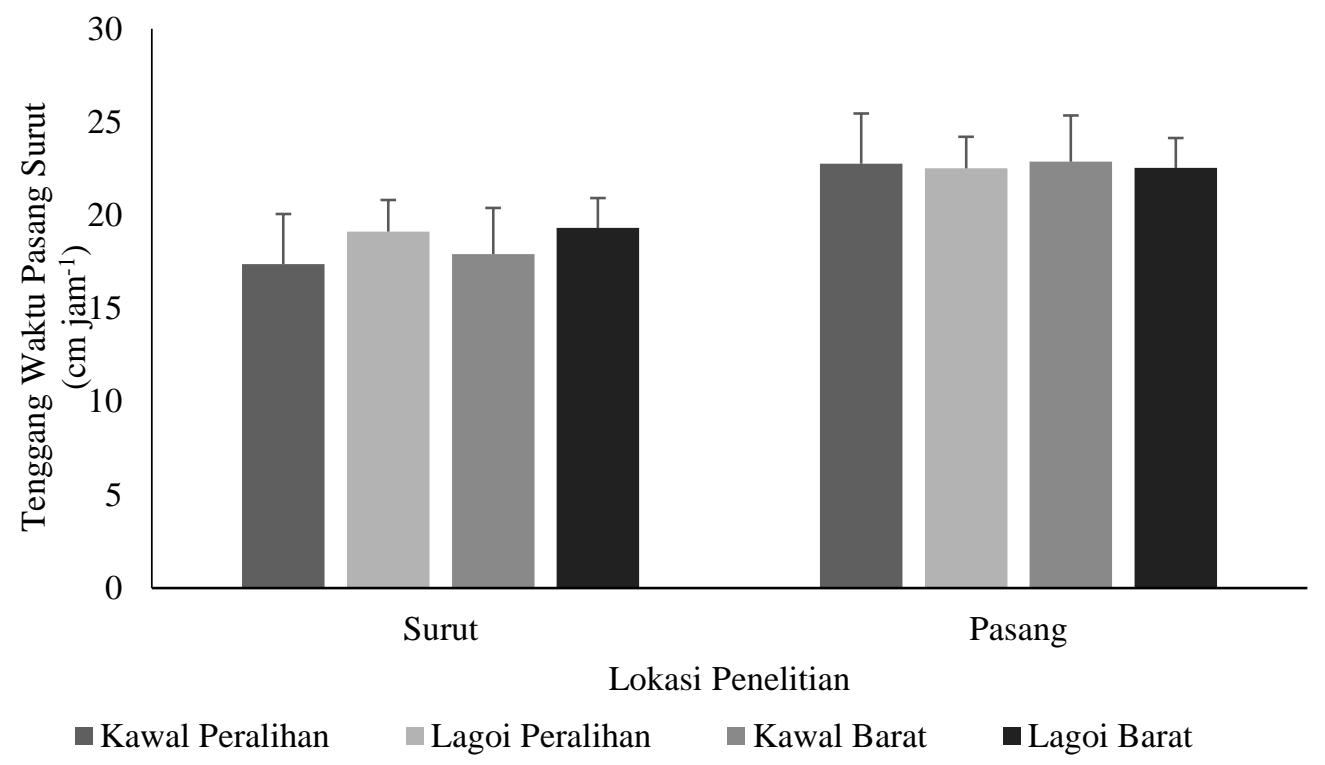

Gambar 9. Rerata Tenggang Waktu Pasang Surut musim peralihan dan Barat di Lokasi Penelitian

Tabel 4. Struktur dan Ketebalan Komunitas Mangrove

\begin{tabular}{|c|c|c|c|c|c|}
\hline Lokasi & Stasiun & Spesies & INP & Spesies Dominan & $\begin{array}{c}\text { Ketebalan } \\
\text { Mangrove }(\mathrm{m}) \\
\end{array}$ \\
\hline \multirow{3}{*}{ Kawal } & KL & Lumnitzera littorea & 300 & Lumnitzera littorea & 100 \\
\hline & KM & $\begin{array}{c}\text { Xylocarpus granatum } \\
\text { Ceriops tagal }\end{array}$ & $\begin{array}{l}150 \\
150\end{array}$ & $\begin{array}{c}\text { Xylocarpus granatum, } \\
\text { Ceriops tagal }\end{array}$ & 120 \\
\hline & KS & $\begin{array}{l}\text { Rhizophora apiculata } \\
\text { Bruguiera gymnorrhiza }\end{array}$ & $\begin{array}{c}260 \\
40\end{array}$ & Rhizophora apiculata & 130 \\
\hline \multirow{3}{*}{ Lagoi } & LL & $\begin{array}{l}\text { Ceriops tagal } \\
\text { Ceriops tagal }\end{array}$ & $\begin{array}{l}300 \\
205\end{array}$ & Ceriops tagal & 80 \\
\hline & LM & $\begin{array}{l}\text { Xylocarpus granatum } \\
\text { Aegiceras corniculatum }\end{array}$ & $\begin{array}{l}20 \\
25\end{array}$ & Ceriops tagal & 90 \\
\hline & LS & $\begin{array}{c}\text { Ceriops tagal } \\
\text { Rhizophora apiculata }\end{array}$ & $\begin{array}{l}160 \\
140\end{array}$ & Ceriops tagal & 100 \\
\hline
\end{tabular}

Tabel 5. Rerata Diameter Batang, Tutupan, Tinggi dan Kerapatan Mangrove

\begin{tabular}{|c|c|c|c|c|c|c|c|}
\hline \multirow{2}{*}{ Lokasi } & \multirow{2}{*}{ Stasiun } & \multirow{2}{*}{$\begin{array}{l}\text { Rerata Diameter } \\
\text { Batang }(\mathrm{cm})\end{array}$} & \multirow{2}{*}{$\begin{array}{c}\text { Tutupan } \\
\text { Mangrove (\%) }\end{array}$} & \multirow{2}{*}{$\begin{array}{c}\text { Tinggi } \\
\text { Mangrove (m) }\end{array}$} & \multicolumn{3}{|c|}{ Kerapatan (ind.ha ${ }^{-1}$ ) } \\
\hline & & & & & Pohon & Anakan & Semai \\
\hline \multirow{4}{*}{ Kawal } & KL & 12,60 & 38,2 & 11,19 & 633 & 33 & 0 \\
\hline & KM & 26,45 & 76,7 & 19,53 & 567 & 233 & 0 \\
\hline & KS & 14,43 & 87 & 15,25 & 1067 & 300 & 470 \\
\hline & Rerata & 17,83 & 67,3 & 15,56 & 755,66 & 188,66 & 156,66 \\
\hline \multirow{4}{*}{ Lagoi } & LL & 8,91 & 89,3 & 12,89 & 3767 & 1033 & 1000 \\
\hline & LM & 17,55 & 89,4 & 15,53 & 1300 & 1567 & 2270 \\
\hline & LS & 9,82 & 89,5 & 11,9 & 2033 & 1232 & 670 \\
\hline & Rerata & 12,09 & 89,4 & 13,44 & 2366,66 & 1277,33 & 1313,33 \\
\hline
\end{tabular}


penebangan liar dan kurangnya regenerasi mangrove. Kerapatan dan ukuran diameter pohon pada tegakan mangrove juga berpengaruh terhadap simpanan karbon di sedimen mangrove. Pendapat ini diperkuat dengan penelitian Mardliyah et al. (2019) bahwa semakin besar ukuran diameter pohon dan kerapatan maka semakin besar simpanan karbonnya dikarenakan semakin banyaknya serasah yang jatuh ke sedimen. Ukuran rerata diameter dan tinggi mangrove (Tabel 5) pada lokasi Kawal lebih tinggi daripada Lagoi. Ukuran rerata diameter batang yang besar menyebabkan Kawal memiliki simpanan karbon lebih tinggi. Hasil penelitian Razai et al, 2018 kawasan konservasi kabupaten Natuna tinggi mangrove mencapai $12,41 \mathrm{~cm}$ dan di Lingga mencapai $6,72 \mathrm{~cm}$. Tetapi pada hasil penelitian ini tidak menunjukan bahwa kerapatan mangrove berpengaruh terhadap simpanan karbon. Dengan demikian, pada penelitian kali ini ukuran dan tinggi mangrove yang lebih berpengaruh daripada kerapatan mangrove.

\section{Pengaruh Karakter Pasang Surut terhadap Dinamika Cadangan Karbon}

Faktor oseanografi pasang surut dapat mempengaruhi dinamika cadangan karbon sedimen mangrove. Pasang surut berperan pada pengangkutan sedimen yang kemudian terperangkat di mangrove. Kordi et al. (2012) berpendapat, saat kondisi pasang intrusi air laut akan membawa partikel sedimen ke belakang mangrove dan ketika surut partikel sedimen tersebut akan tertarik kembali bersama air laut yang tertarik ke laut kecuali yang terperangkap dalam akar mangrove dan sedimen yang dapat mengendap lebih cepat. Berdasarkan hasil penelitian Kawal dan Lagoi memiliki tipe pasang surut yang sama yaitu campuran condong harian ganda dimana pada satu hari terdapat dua kali pasang dan surut (Ayunarita et al., 2017). Tipe pasang surut yang sama tetapi ketinggian pasang dan surut di Kawal dan Lagoi beberda. Hasil penelitian menunjukan perbedaan rerata tenggang waktu ketika surut antara Lagoi dan Kawal cukup signifikan. Hal ini sesuai dengan penelitian bahwa semakin besar simpanan karbon maka semakin rendah rerata tenggang waktu surut. Waktu yang diperlukan sedimen untuk mengendap lebih sedikit dan serasah yang keluar lebih cepat sehingga serasah yang mengendap lebih sedikit di Lagoi daripada Kawal. Selanjutnya untuk rerata tenggang waktu pasang antara Kawal dan Lagoi perbedaannya tidak cukup signifikan. Purnobasuki (2011) menyatakan bahwa, adanya air pasang menyebabkan siklus karbon yang berjalan lebih lambat dikarenakan kondisi anaerob akibat tergenang air sehingga proses dekomposisi berjalan lebih lambat dan karbon yang dilepaskan kembali ke alam juga lebih sedikit. Sedimen yang ada pada mangrove merupakan akumulasi sedimen dari waktu ke waktu.

\section{KESIMPULAN}

Berdasarkan hasil penelitian, rerata simpanan karbon sedimen mangrove di Kawal memiliki nilai lebih tinggi dibanding Lagoi dengan nilai yaitu 1390,77 ton $\mathrm{C} \mathrm{ha}^{-1}$ dan 764,82 ton $\mathrm{C} \mathrm{ha}^{-1}$. Simpanan karbon sedimen mangrove lebih besar ditemukan di wilayah yang memiliki ukuran butir lebih halus, dengan arus dan tenggang waktu pasang surut yang lebih rendah, rerata ukuran dan tinggi mangrove yang lebih besar. Hasil penelitian juga menujukan bahwa mangrove dominan di Kawal adalah Rhizophora apiculata dan di Lagoi Ceriops tagal. Rhizophora apiculata memiliki simpanan karbon yang lebih besar dari Ceriops tagal dikarenakan memiliki sistem perakaran antar spesies yang baik dan daunnya lebih lebar, sehingga serasah yang jatuh lebih banyak. Diharapakan untuk penelitian selanjutnya terdapat perhitungan produktivitas serasah dan kecepatan arus saat arus pasang dan arus surut, karena pada saat air pasang serasah ada yang terbawa arus dan tertinggal.

\section{UCAPAN TERIMA KASIH}

Terimakasih kepada Kelompok Penelitian Bioekologi dan Vegetasi Laut (KPBioVeLa), Pusat Penelitian Oseanografi Lembaga Ilmu Pengetahuan Indonesia (P2O LIPI) atas diizinkanya penulis bergabung dalam proyek penelitian.

\section{DAFTAR PUSTAKA}

Agus, F., Hairiah, K., \& Mulyani, A. 2011. Pengukuran Cadangan Karbon Tanah Gambut. World Agroforesty CentreICRAF, SEA Regional Office dan Balai Besar Penelitian dan Pengembangan Sumberdaya Lahan Pertanian (BBSDLP). Bogor.

Alongi, D.M. 2012. Carbon sequestration in 
mangrove forests. Carbon management, 3(3):313-322.

Analuddin, A., Jamili, J. \& Dafid, P. 2016. Ekspor Karbon Dari Serasah Daun Mangrove Di Taman Nasional Rawa Aopa Watumohai. Journal of Biological Research, 3(1): 321327.

Ati, R.N.A., Agustin, R.,Terry, L.K., Nasir, S., Mariska, A., August, D., Peter, M., Hadiwijaya, L.S. \& Andreas A.H. 2014. Stok Karbon Dan Struktur Komunitas Mangrove Sebagai Blue Carbon Di Tanjung Lesung, Banten. Jurnal Segara, 10(2):119-127.

Ayunarita, S., Elizal \& Musrifin. 2017. Studi Pola Arus, Pasang Surut Dan Gelombang Di Perairan Pantai Pelawan Desa Pangke Kecamatan Meral Kabupaten Karimun Provinsi Kepulauan Riau. Jurnal Fakultas Perikanan Dan Kelautan Universitas Riau. Pekanbaru.

Azzahraa, F.S., Suryanti, S. \& Sigit, F. 2020. Estimasi Serapan Karbon Pada Hutan Mangrove Desa Bedono, Demak, Jawa Tengah. Journal of Fisheries and Marine Research, 4(2):308-315

Chmura, G.L., Anisfeld, S.C., Cahoon, D.R. \& Lynch, J.C. 2003. Global carbon sequestration in tidal, saline wetland soils. Global biogeochemical cycles, 17(4): 1-12. doi: 10.1029/2002GB001917

Dahuri, R. 2003. Keanekaragaman Hayati Laut Aset Pembangunan Berkelanjutan Indonesia. Gramedia Pustaka Utama. Jakarta.

Dharmawan, I.W.E., Suyarso., Yaya, I.U., Bayu, P., \& Pramudji. 2020. Panduan monitoring struktur komunitas mangrove Indonesia. Bogor: PT Media Sains Nasional.

Donato, D.C., Kauffman, J.B., Murdiyarso, D., Kurnianto, S., Stidham, M. \& Kanninen, M. 2012. Mangrove adalah salah satu hutan terkaya karbon di kawasan tropis. Brief Cifor, 12:1-10.

Gemilang, W.A., Ulung, J.W., Guntur, A.R. \& Ruzana, D. 2018. Karakteristik Sebaran Sedimen Pantai Utara Jawa Studi Kasus: Kecamatan Brebes Jawa Tengah. Jurnal Kelautan Nasional, 13(2):65-74

Hadi, A.M., Mimien, H.I. \& Suhadi. 2015. Karakteristik Morfo-Anatomi Struktur Vegetatif Spesies Rhizopora Apiculata (Rhizoporaceae). Jurnal Pendidikan,
1(9):1688-1692

Hakim, M.A., Nana, K. T. M., \& Andin, Irsadi. 2016. Estimasi Stok Karbon Mangrove di Dukuh Tapak Kelurahan Tugurejo Kota Semarang. Jurnal Unnes. 5(2):87-94.

Hamunal, B., Rosye H.R. T., John, D. K., Lisiard, D., Ervina, I., Maklon, W., Yunus Y.P. P. \& Kalvin, P. 2018. Studi Karakteristik Pasang Surut Perairan Laut Mimika, Provinsi Papua. Jurnal Acropora Ilmu Kelautan dan Perikanan Papua, 1(1):19-28

Hickmah, N., L. Maslukah, S. Y. Wulandari, D. N. Sugianto, and A. Wirasatriya. 2021. Kajian Stok Karbon Organik dalam Sedimen di Area Vegetasi Mangrove Karimunjawa. Indonesian Journal of Oceanography, 3(4):88-95.

Ismunarti, D.H., Zainuri, M., Sugianto, D.N. \& Saputra, S.W. 2020. Pengujian Reliabilitas Instrumen Terhadap Variabel Kontinu Untuk Pengukuran Konsentrasi Klorofil-a Perairan. Buletin Oseanografi Marina, 9(1): $1-8$.

Kauffman, J.B. \& Donato, D.C. 2012. Protocols for the measurement, monitoring, and reporting of structure, biomass and carbon stocks in mangrove forests. CIFOR Work. Pap. 86. Cent. Int. For. Res. Bogor, Indones.

Komiyama, A., Poungparn, S. \& Kato, S. 2005. Common allometric equations for estimating the tree weight of mangroves. Journal of Tropical Ecology, 21(4):471477.

Kordi MGH. 2012. Ekosistem Mangrove: Potensi, fungsi, dan pengelolaan. Rineka Cipta. Jakarta.

Lestariningsih, W.A., Nirwani S. \& Rudhi P. 2018. Estimasi Cadangan Karbon pada Kawasan Mangrove di Desa Timbulsloko, Demak, Jawa Tengah. Buletin Oseanografi Marina, 7(2):121-130.

Lewerissa, Y.A., Sangaji, M. \& Latumahina, M. B. 2018. Pengelolaan mangrove berdasarkan tipe substrat di perairan Negeri Ihamahu Pulau Saparua. Triton: Jurnal Manajemen Sumberdaya Perairan, 14(1):19.

Mahmudi., Soemarno., Marsoedi \& Diana, A. 2011. Produksi Dan Dekomposisi Serasah Rhizophora Mucronata Serta Kontribusinya Terhadap Nutrien Di Hutan Mangrove Reboisasi, Nguling Pasuruan. Jurnal 
Berkala Penelitian Hayati, 6:19-24.

Mardliyah, R., Raden, A. \& Rudhi, P. 2019. Estimasi Simpanan Karbon Pada Ekosistem Mangrove Di Desa Pasar Banggi Dan Tireman, Kecamatan Rembang Kabupaten Rembang. Journal of Marine Research, 8 (1):62-68

Maslukah, L., Elis, I., \& Azis, R. 2014. Sebaran Material Organik dan Zat Hara Oleh Arus Pasang Surut di Muara Sungai Demaan, Jepara. Jurnal Ilmu Kelautan, 19(4):189194

Massugito. 2016. Analisis Cadangan Karbon pada Ekosistem Hutan Mangrove di Kawasan Pesisir Kuala Indragiri Provinsi Riau. Skripsi pada Jurusan Ilmu Kelautan Fakultas Perikanan dan Kelautan Universitas Riau, Pekanbaru.

McIvor, A., Tom, S., Iris, M. \& Mark, S. 2013. The Response Of Mangrove Soil Surface Elevation To Sea Level Rise. Natural Coastal Protection Series. Cambridge Coastal Research Unit Working Paper 42.

Murdiyarso, D., Purbopuspito, J., Kauffman, J.B., Warren, M.W., Sasmito, S.D., Donato, D.C., Manuri, S., Krisnawati, H., Taberima, S. \& Kurnianto, S. 2015. The potential of Indonesian mangrove forests for global climate change mitigation. Nature climate change, 5(12):1089-1092.

Nontji, A. 2003. Laut Nusantara. Djambatan. Jakarta.

Purnobasuki, H. 2011. Peranan Mangrove dalam Perubahan Iklim. Buletin PSL Universitas Surabaya, 26.

Rampengan, R. M. 2013. Amplitudo Konstanta Pasang Surut M2, S2, K1, Dan O1 Di Perairan Sekitar Kota Bitung Sulawesi Utara. Jurnal Ilmiah Platax, 1(3):118-124.

Round, F.C. 1971. Benthic Marine Diatoms. Department of Botany. The University of Bristol. England.

Suryono, S.N., Wibowo, E., Ario, R. \& Rozy, E.F. 2018. Estimasi Kandungan Biomassa dan Karbon di Hutan Mangrove Perancak Kabupaten Jembrana, Provinsi Bali. Buletin Oseanografi Marina, 7 (1):1-8.

Triatmodjo, B. 2012. Teknik Pantai. Beta Offset. Yogyakarta.

Verisandria, R.J., Joshian N.W., Schaduw., Calvyn, F.A., Sondak, M.O., Antonius, R., \& Jety, R. 2018. Estimasi Potensi Karbon Pada Sedimen Ekosistem Mangrove Di Pesisir Taman Nasional Bunaken Bagian Utara. Jurnal Pesisir dan Laut Tropis, 6(1):81-97 